\title{
Fire History of the Lamar River Drainage Yellowstone National Park
}

\author{
STEPHEN W. BARRETT \ SYSTEMS FOR ENVIRONMENTAL MANAGEMENT \\ Stephen F. Arno ^ InTERmountain Research Station ^ USDA Forest SERVICE \\ MisSOULA
}

\section{$\downarrow$ INTRODUCTION}

In this paper we discuss the first phase of a 3-year effort to document the fire history of Yellowstone National Park's (YNP) Lamar River drainage southeast of Soda Butte Creek. The overall goal of the study was to provide managers with a more complete understanding of YNP natural fire regimes. Specific objectives were:

1. Determine natural (pre-1900) fire periodicities, severities, burning patterns, and post-fire succession within the study area's major forest types (Douglas fir/ grassland, lodgepole pine/subalpine fir/ spruce, whitebark pine/lodgepole pine/ subalpine fir, and whitebark pine/subalpine fir timberline habitats);

2. document and map the pre-1988 forest age-class mosaic; and

3. digitize the age-class mosaic map for the YNP's GIS data base. This study is considered especially timely because the 1988 fires destroyed much evidence of area fire history.

Our sampling in 1989 focused on a 24,000 ha area encompassing the Cache Creek drainage, which was severely burned in 1988. The forest age-class mosaic was sampled by increment boring and sawing fire scar samples from old trees (Arno and Sneck 1977, Barrett and Arno 1988). Aerial photographs were used to map the pre-1988 forest age-class mosaic. Data was digitized for the park's GIS data base. Information from the YNP fire atlas also was useful in interpreting fire patterns during the post-1900 period.

\section{$\downarrow$ Fire Regimes}

Sampling at 43 sites produced 17 fire scar cross sections and 182 increment cores from fire initiated age-classes. The Master Fire Chronology derived from sampling the forest age-class mosaic area extends from 1756 to 1989 . There is little fire history evidence prior to 1956 because a large fire (ca. 1756), and subsequent stand replacing fires, obliterated most evidence of earlier lodgepole pine age classes. Additionally, fire scarred Douglas-fir (Pseudotsuga taxifolia) in 4 stands in the Lamar Valley grassland/forest ecotone provided a relatively continuous record of surface fires back to 1534. Sampling produced evidence of 11stand replacing fires during the 233 year period. During this period ten fires produced the the pre-1988 age-class mosaic before widespread stand replacing fires occurred in 1988. Data yielded a mean fire interval (MFI) of 23 years for the study area. That is, a stand replacing fire occurred somewhere in the $24,000 \mathrm{ha}$ study area on an average of every 23 years.

Moderate-to-large fires, defined here to be in excess of 400 ha, occurred at least 4 times during the period, yielding a MFI of 78 years for such fires. Thus an average of at least 1 of every 3 stand replacing fires grew to large size. Two extensive fires occurred during the 233 year period--the 1756 fire apparently burned a large portion of the study area, followed by a 232 year interval before the next drainage-wide fire in 1988.

There was evidence of several fire regimes in the study area. For example, dry Douglas-fir stands adjacent to valley grasslands experienced primarily surface fires after short intervals (houston 1973). The 
300 to 500 year old Douglas-firs in these areas often have 6 or more fire scars each, and 4 stands near Soda Butte Creek produced evidence of 15 fires between ca. 1534 and 1989. The MFI between 1534 and 1886 (Houston's [1973] "Prehistoric Period") was 29 years, and 32 years respectively for the entire sample period. Most fire intervals during the "Prehistoric Period" were less than 30 years long. As of 1989, however, 3 of the 4 Douglas-fir stands had not burned for 119 years or more, an unusually long fire interval for this forest type (Houston 1973, Arno 1980, Arno and Gruel 1986) and a likely result of efficient fire suppression in northern YNP (Houston 1973).

A different fire regime occurred in the adjacent lodgepole pine (Pinus contorta) forests. Relatively moist north slope stands experienced predominantly stand replacing fires at ca. 150-250 year intervals (8-stand mean: 202 yr). Stand structure data show that moist-site stands nearly always had a one-aged seral component and lacked fire scarred trees, suggesting that stand replacing fires prevailed. On south aspects, intervals between stand replacing fires were slightly shorter (10-stand mean: $178 \mathrm{yr}$ ) and trees occasionally had single fire scars. These partial replacement fires had killed as many half of the stand dominants and triggered a new seral age class $20-80$ years after stand initiation.

Results to date differ substantially from Romme's (1982) study of lodgepole pine on YNP's central plateau. In that area, unproductive stands (sparse live fuels), very slow fuel accretion, and gentle terrain often retard the development of large stand replacing fires, resulting in very long intervals (ca. 300-400 yr) between stand replacing fires. By comparison, stands in the Cache Creek study area occupy sites on steeper terrain,, where south slope fuels are more prone to drying and where fuel pre-heating occurs more readily during fires. It is possible that some fire intervals in the Cache Creek data are uncharacteristically short because the severe 1988 fire provided the only complete fire intervals in the data. Several factors, however, suggest that a ca. 150-250 year fire interval range is in fact characteristic:

1. the lodgepole pine mosaic contained virtually no stands older than 250 years, [older age classes would exist if the area had experienced very long fire intervals (Romme 1982)],

2. the 1988 fire evidently was not unprecedented because evidence of another extensive fire (ca. 1756) occurs in the data, and
3. the Cache Creek fire intervals are similar to those found in other studies of lodgepole pine in mountain terrain (Arno 1980, Barrett et al. [in prep]). Moreover, fire frequencies actually may have been lengthened somewhat by fire suppression because the study area is adjacent to the Lamar Valley grassland where many ignitions have been suppresses since the late 1880s (Houston 1973, unpub. reports on file: YNP Fire Cache).

\section{$\downarrow$ Effects of Fire Suppression}

The data were examined for 3 time periods during the time span of the fire history data (Houston 1973, Taylor 1974, Romme and Despain 1989): 1) the Prehistoric Period (pre-1886), 2) Complete Suppression Policy 1886-1976), and 3) the Natural Fire Program (1976 to present). Fire suppression was effective in remote areas (subsequent phases of this study) for only about 30 years before the natural fire program (Romme and Despain 1989), suggesting a logical fourth category for remote areas between 1945-1976 (Fig. 5). However, since Cache Creek adjoins grasslands where many fires were suppressed after the park's inception (Houston 1973), the 1886-1976 period would best apply to our study area.

Historically, lightning ignited most fires in YNP. Humans undoubtedly contributed to ignition frequency during the Prehistoric Period, particularly near grassland valleys (Houston 1973). For example, the Lamar Valley and adjacent Soda Butte Creek drainage has long been a major travel and hunting route for Indians, miners, and others (Houston 1973). Written records state that Indians caused a major fire in 1870 in the lower and mid-Lamar Valley, apparently to drive game (Houston 1973). Interestingly, data for the nearby Cache Creek study area indicate that a ca. 1870 fire replaced a substantial portion of the area's lodgepole pine age-classes. Houston's (1973) fire scar data showed a marked decrease in fire frequency on the northern range after YNP's inception in 1886, and Houston's (1982) examination of old photographs found a concurrent increase in shrub and tree densities in grasslands. Fire frequency data from Douglas -fir stands in the Cache Creek study area agree with Houston's (1973) findings, suggesting a "relatively long" period of fire suppression in those areas.

The YNP fire atlas also produced evidence of fire suppression, particularly near the road corridor in the 
Lamar-Soda Butte valley. Fourteen fires were recorded for the study area between 1930 and 1989--2 of which occurred during the period of theNatural Fire Program (1988 and a 1986 spot fire). The 1988 fire was the only significant stand replacing event during the 6 decade period, and most of the 12 suppressed ignitions were less than a hectare in size. Moreover, 8 of the 12 suppressed fires occurred in grassland near the Lamar Valley road, 3 of which were caused by humans.

Several factors suggest that some suppressed fires had potential to become important stand replacing fires:

1) 6 of 12 suppressed fires occurred during known drought years $(1936,1940,1949$,m 960) (unpub. reports on file: YNP Fire Atlas, Romme and Despain 1989),

2) most suppressed ignitions occurred in grassland fuels where fires can grow rapidly and spread to adjacent forests, and

3) efficiency of detection and suppression apparently decreased with increasing distance from roads, allowing backcountry fires to spread to substantial size before eventual suppression. Future phases of this study will provide more data on natural fire regimes for the Lamar River drainage, permitting a more refined comparison of pre- and post 1900 fire patterns.

\section{$\downarrow$ Literature Cited}

Arno, S. F., and K. M. Sneck. 1977. A method for determining fire history in coniferous forests of the mountain west. Gen. Tech. Rep. INT-42. Ogden, UT: U.S. Department of Agriculture, Forest Service, Intermountain Forest and Range Experiment Station.
1980. Forest fire history in the Northern

Rockies. J. For. 78:450-465.

Arno, S. F., K. M. Sneck, and G. E. Gruell. 1986. Douglas-fir encroachment into mountain grasslands in southwestern Montana. J. Range Manage. 39:272-276.

Barrett, S. W., and S. F. Arno. 1988. Increment borer methods for determining fire history in coniferous forests. Gen. Tech. Rep. INT-244. Ogden, UT: U.S. Department of Agriculture, Forest Service, Intermountain Research Station.

Barrett, S. W., S. F. Arno, and C. H. Key. Fire Regimes of Western Larch-Lodgepole Pine forests in Glacier National Park, Montana. (manuscript in preparation).

Houston, D. B. 1973. Wildfires in northern Yellowstone National Park. Ecology 54:1111-1117.

1982. The northern Yellowstone elk. Macmillan Pub. Co., New York.

Romme, W. H. 1982. Fire and landscape diversity in subalpine forests of Yellowstone National Park. Ecol. Monogr. 52:199-221.

Romme, W. H., and D. Despain. 1989. The long history of fire in the Greater Yellowstone Ecosystem. West. Wildl. 15:10-17.

Taylor, D. L. 1974. Forest fires in Yellowstone National Park. J. For. Hist. 18:68-77. 